\title{
Investigating factors on commercializing ideas: Empirical study on SMEs in food industry
}

\author{
Mostafa Dastour and Abdollah Naami*
}

Department of Business and management, South Tehran Branch, Islamic Azad University, Tehran, Iran

\begin{tabular}{|c|c|}
\hline C HRON I C LE & ABSTRACT \\
\hline $\begin{array}{l}\text { Article history: } \\
\text { Received July 18, } 2014 \\
\text { Accepted January } 172015 \\
\text { Available online } \\
\text { January } 172015 \\
\text { Keywords: } \\
\text { Food industry } \\
\text { Commercializing idea } \\
\text { Innovation }\end{array}$ & $\begin{array}{l}\text { This paper presents an empirical study to investigate different factors for commercializing } \\
\text { ideas in food industry. The study uses structural equation modeling, by designing a } \\
\text { questionnaire in Likert scale, and distributes it among } 218 \text { randomly selected experts in food } \\
\text { industry in city of Tehran, Iran. Cronbach alpha has been calculated as } 0.864 \text {, which is well } \\
\text { above the acceptable level. The study uses structural equation modeling as well as some } \\
\text { descriptive tests to examine the hypotheses of the survey. The results confirm that management } \\
\text { of ideas, the feasibility of the ideas, market research and advocacy strategies influence the most } \\
\text { on commercializing ideas in food industry. }\end{array}$ \\
\hline
\end{tabular}

\section{Introduction}

During the past few years, innovation has been primary key for market development in many countries. Market is witness of facing new innovative products such as Google glass from Google and Iphone from Apple, which have revolutionized the market (Kreiser et al., 2002; Nicholson \& de WaalAndrews, 2005; Gartner, 2007). Many people ask how to develop innovative ideas in one country and present it for world's market. In fact, when entrepreneurs learn more about the factors such as culture (Turró et al. 2013) influencing new product development, they may have a better chance to reach creative ideas (Hayton et al., 2002; Brinkley, 2006). There are several studies on learning more about the method for managing entrepreneurial economies. Audretsch and Thurik (2004), for example, studied the distinction between the models of the managed and entrepreneurial economies. They explained why the model of the entrepreneurial economy (Creswell, 2002; Sarasvathy \& Venkataraman, 2011) could be a more appropriate reference than other methods. Hayton et al., (2002) studied entrepreneurship re-emerged as a key agenda item of economic policy-makers across Europe.

\footnotetext{
* Corresponding author

E-mail address: naami122@yahoo.com (A. Naamj)

(C) 2015 Growing Science Ltd. All rights reserved.

doi: 10.5267/j.uscm.2015.1.001
} 
Duane Ireland and Webb (2007) state that most companies face the need to be increasingly nimble and adaptive to have a competitive abilities to survive. They explained strategic entrepreneurship as the necessary tools through which firms concurrently exploit their current competitive advantages while exploring for some existing opportunities. Achieving a balance between exploration and exploitation includes more than merely assigning resources evenly between the two processes. The issue of entrepreneurship has evolved over time and many small business clearly changed (Verheul et al., 2002; Thurik \& Wennekers (2004).

In some countries, governments start promoting entrepreneurship activities from high schools at early stages. Soysekerci and Erturgut (2010), for instance, discussed improvement of non-governmental organization entrepreneurship in vocational schools in Turkey. Danaei and Normohammadi (2013) studied the relationship between intellectual capital and organizational entrepreneurship and reported some positive correlation between the two factors. Derakhshandeh (2013) first studied the effect of entrepreneurship on growth of economy over the period 2005- 2011. Then they investigated the effect of four factors including Gross domestic product per worker, Growth in capital per worker, New firm creation and Technological innovation intensity on economic growth. They reported that gross domestic product per worker was the only variable, which was statistically meaningful and the impact of other three variables including growth in capital per worker, new firm creation and technological innovation intensity were not statistically meaningful.

Karimi et al. (2012) performed a comparative study on emotional intelligence and cognitive between successful and unsuccessful entrepreneurs and their survey indicated that emotional intelligence could substantially impact on the success of entrepreneurs. Nasrabadi et al. (2012) explained three entrepreneurship opportunities including universities, technical and vocational centers and women. Universities are capable of educating highly skilled people and send them to business and they have the ability to create new ideas. Technical and vocational centers are, in fact, the best place for training basic or recent advances in technological skills through short term or long term planning. This survey described that women could be considered as a good source of job creation.

\section{The proposed method}

This paper presents an empirical study to investigate different factors for commercializing ideas in food industry. The study uses structural equation modeling, by designing a questionnaire in Likert scale, and distributes it among some randomly selected experts in food industry in city of Tehran, Iran. The population of this survey includes all experts in governmental agencies and the sample size is calculated as follows,

$$
N=Z_{\alpha / 2}^{2} \frac{p \times q}{e^{2}},
$$

where $N$ is the sample size, $p=1-q$ represents the probability, $z_{\alpha / 2}$ is CDF of normal distribution and finally $\varepsilon$ is the error term. For our study we assume $p=0.5, z_{\alpha / 2}=1.96$ and $e=0.05$, the number of sample size is calculated as $N=218$. Kaiser-Meyer-Olkin Measure of Sampling Adequacy is equal to 0.795. In addition, Bartlett's Test of Sphericity represents a Chi-Square value of 2290.74 with df = 703 and Sig. $=0.000$. Table 1 demonstrates the results of some basic statistics associated with the survey.

The implementation of the proposed study of this paper applies structural equation modelling using LISREL software package and the method sensitive to skewness of the data. According to Table 1, all statistics are within acceptable levels and therefore, there is no need to remove any data from the survey. Table 2 presents preliminary results of our survey. 
Table 1

The results of some basic statistics

\begin{tabular}{|c|c|c|c|c|c|c|c|c|}
\hline & \multirow[b]{2}{*}{$\begin{array}{c}\mathrm{N} \\
\text { Statistic }\end{array}$} & \multirow[b]{2}{*}{$\begin{array}{c}\text { Minimum } \\
\text { Statistic }\end{array}$} & \multirow[b]{2}{*}{$\begin{array}{l}\text { Maximum } \\
\text { Statistic }\end{array}$} & \multicolumn{2}{|c|}{ Skewness } & \multicolumn{2}{|c|}{ Kurtosis } \\
\hline & & & & & Statistic & $\begin{array}{c}\text { Std. } \\
\text { Error }\end{array}$ & Statistic & $\begin{array}{c}\text { Std. } \\
\text { Error }\end{array}$ \\
\hline q1 & $\begin{array}{l}\text { Other researchers have documented } \\
\text { experience }\end{array}$ & 218 & 1 & 5 & $-\overline{4}$ & 0.165 & $\begin{array}{c}- \\
0.768\end{array}$ & 0.328 \\
\hline q2 & $\begin{array}{l}\text { The success rate in the experimental } \\
\text { stage }\end{array}$ & 218 & 1 & 5 & $\overline{-}-$ & 0.165 & $\begin{array}{c}- \\
0.497\end{array}$ & 0.328 \\
\hline q3 & Financial Feasibility & 218 & 1 & 5 & - & 0.165 & -0.86 & 0.328 \\
\hline q4 & $\begin{array}{l}\text { Technical and administrative aspects } \\
\text { of the idea }\end{array}$ & 218 & 1 & 5 & $\begin{array}{c}- \\
0.548\end{array}$ & 0.165 & $\begin{array}{c}- \\
0.671\end{array}$ & 0.328 \\
\hline q5 & Industry & 218 & 1 & 5 & - & 0.165 & - & 0.328 \\
\hline q6 & Competitiveness of business & 218 & 1 & 5 & - & 0.165 & - & 0.328 \\
\hline q7 & Government incentives & 218 & 1 & 5 & - & 0.165 & - & 0.328 \\
\hline q8 & $\begin{array}{l}\text { Analyze and evaluate the needs of the } \\
\text { market }\end{array}$ & 218 & 1 & 5 & $\begin{array}{c}- \\
0.597\end{array}$ & 0.165 & 0.374 & 0.328 \\
\hline q9 & Insurance Research & 218 & 1 & 5 & - & 0.165 & - & 0.328 \\
\hline q10 & Technical feasibility & 218 & 1 & 5 & - & 0.165 & - & 0.328 \\
\hline q11 & Identify the target market & 218 & 1 & 5 & - & 0.165 & - & 0.328 \\
\hline q12 & $\begin{array}{l}\text { Rates in the commercialization of } \\
\text { ideas }\end{array}$ & 218 & 1 & 5 & $\overline{-}$ & 0.165 & $\begin{array}{c}- \\
0.555\end{array}$ & 0.328 \\
\hline q13 & Private sector participation & 218 & 1 & 5 & - & 0.165 & - & 0.328 \\
\hline q14 & Given the longevity of ideas & 218 & 1 & 5 & - & 0.165 & - & 0.328 \\
\hline q15 & Attractive for investment & 218 & 1 & 5 & - & 0.165 & - & 0.328 \\
\hline q16 & Strategic needs of the country & 218 & 1 & 5 & - & 0.165 & - & 0.328 \\
\hline q17 & Detection of new ideas & 218 & 1 & 5 & - & 0.165 & - & 0.328 \\
\hline q18 & Subject knowledge & 218 & 1 & 5 & - & 0.165 & - & 0.328 \\
\hline q19 & Participation in venture capital & 218 & 1 & 5 & - & 0.165 & - & 0.328 \\
\hline q20 & Share of researchers & 218 & 1 & 5 & - & 0.165 & - & 0.328 \\
\hline q21 & $\begin{array}{l}\text { Protection of personal and spiritual } \\
\text { Market }\end{array}$ & 218 & 1 & 5 & $\begin{array}{c}- \\
0.521\end{array}$ & 0.165 & $\begin{array}{c}- \\
0.631\end{array}$ & 0.328 \\
\hline q22 & Acceptance of commercial risk & 218 & 1 & 5 & - & 0.165 & - & 0.328 \\
\hline q23 & Innovation & 218 & 1 & 5 & - & 0.165 & - & 0.328 \\
\hline q24 & Administrative bureaucracy problems & 218 & 1 & 5 & - & 0.165 & -0.69 & 0.328 \\
\hline q25 & Market demand for certain & 218 & 1 & 5 & - & 0.165 & - & 0.328 \\
\hline q26 & Identify effective marketing tool & 218 & 1 & 5 & - & 0.165 & -0.42 & 0.328 \\
\hline q27 & Market-oriented research ideas & 218 & 1 & 5 & - & 0.165 & -0.44 & 0.328 \\
\hline q28 & Pricing appropriate by the buyer Ideas & 218 & 1 & 5 & - & 0.165 & - & 0.328 \\
\hline q29 & The pattern of business process & 218 & 1 & 5 & - & 0.165 & - & 0.328 \\
\hline q30 & Sift Ideas & 218 & 1 & 5 & - & 0.165 & - & 0.328 \\
\hline q31 & The possibility of having an idea & 218 & 1 & 5 & - & 0.165 & - & 0.328 \\
\hline q32 & $\begin{array}{l}\text { Responsibility in solving community } \\
\text { problems }\end{array}$ & 218 & 1 & 5 & $\begin{array}{c}- \\
0.715\end{array}$ & 0.165 & 0.003 & 0.328 \\
\hline q33 & $\mathrm{CE}$ & 218 & 1 & 5 & -0.41 & 0.165 & - & 0.328 \\
\hline q34 & Learning organizations & 218 & 1 & 5 & - & 0.165 & - & 0.328 \\
\hline q35 & Participatory Management & 218 & 1 & 5 & - & 0.165 & - & 0.328 \\
\hline q36 & $\begin{array}{l}\text { Interaction with industry and research } \\
\text { teams }\end{array}$ & 218 & 1 & 5 & $\overline{-}-$ & 0.165 & $\begin{array}{c}- \\
0.815\end{array}$ & 0.328 \\
\hline q37 & Support the organization of ideas & 218 & 1 & 5 & - & 0.165 & - & 0.328 \\
\hline q38 & Interactions & 218 & 1 & 5 & -0.8 & 0.165 & 0.336 & 0.328 \\
\hline
\end{tabular}


The results of Table 2 indicate that there were 12 factors out of 35 factors whose eigenvalues were above one and can be considered for the next step of the survey. In addition Fig. 1 shows details of Scree plot. In addition, Table 3 and Table 4 present detail of principal component analysis before and after rotation.

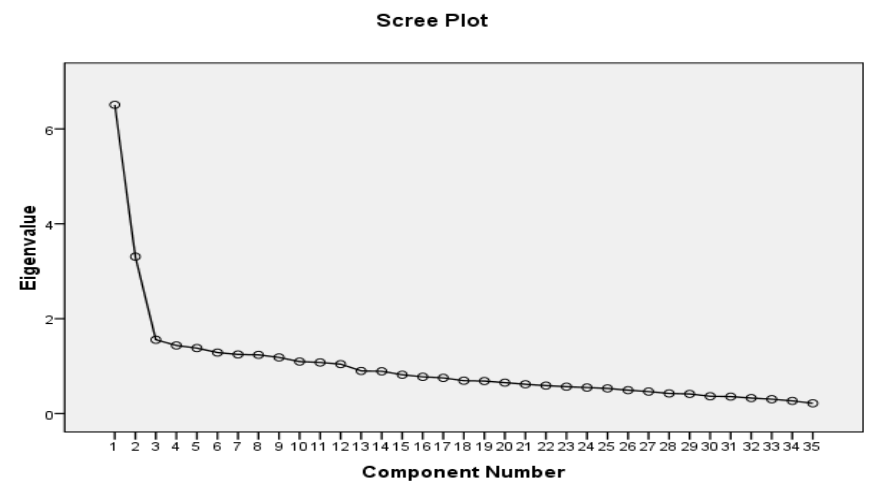

Fig. 1. The summary of Scree plot

Table 2

The summary of some preliminary results of the implementation of structural equation modelling

\begin{tabular}{|c|c|c|c|c|c|c|c|c|c|}
\hline \multirow[b]{2}{*}{ Component } & \multicolumn{3}{|c|}{ Initial Eigen values } & \multicolumn{3}{|c|}{ Extraction Sums of Squared Loadings } & \multicolumn{3}{|c|}{ Rotation Sums of Squared Loadings } \\
\hline & Total & $\begin{array}{c}\% \text { of } \\
\text { Variance }\end{array}$ & $\begin{array}{c}\text { Cumulative } \\
\%\end{array}$ & Total & $\begin{array}{c}\% \text { of } \\
\text { Variance }\end{array}$ & $\begin{array}{c}\text { Cumulative } \\
\%\end{array}$ & Total & $\begin{array}{c}\% \text { of } \\
\text { Variance }\end{array}$ & $\begin{array}{c}\text { Cumulative } \\
\%\end{array}$ \\
\hline 1 & 6.508 & 18.594 & 18.594 & 6.508 & 18.594 & 18.594 & 3.258 & 9.307 & 9.307 \\
\hline 2 & 3.308 & 9.451 & 28.045 & 3.308 & 9.451 & 28.045 & 2.257 & 6.447 & 15.755 \\
\hline 3 & 1.556 & 4.445 & 32.49 & 1.556 & 4.445 & 32.49 & 2.088 & 5.965 & 21.72 \\
\hline 4 & 1.435 & 4.101 & 36.591 & 1.435 & 4.101 & 36.591 & 1.963 & 5.608 & 27.327 \\
\hline 5 & 1.38 & 3.943 & 40.534 & 1.38 & 3.943 & 40.534 & 1.853 & 5.294 & 32.621 \\
\hline 6 & 1.286 & 3.674 & 44.208 & 1.286 & 3.674 & 44.208 & 1.763 & 5.038 & 37.659 \\
\hline 7 & 1.246 & 3.561 & 47.77 & 1.246 & 3.561 & 47.77 & 1.737 & 4.962 & 42.621 \\
\hline 8 & 1.237 & 3.534 & 51.304 & 1.237 & 3.534 & 51.304 & 1.717 & 4.907 & 47.527 \\
\hline 9 & 1.183 & 3.379 & 54.683 & 1.183 & 3.379 & 54.683 & 1.514 & 4.327 & 51.854 \\
\hline 10 & 1.096 & 3.132 & 57.815 & 1.096 & 3.132 & 57.815 & 1.489 & 4.255 & 56.109 \\
\hline 11 & 1.077 & 3.078 & 60.894 & 1.077 & 3.078 & 60.894 & 1.372 & 3.92 & 60.029 \\
\hline 12 & 1.043 & 2.979 & 63.873 & 1.043 & 2.979 & 63.873 & 1.345 & 3.844 & 63.873 \\
\hline 13 & 0.899 & 2.567 & 66.44 & & & & & & \\
\hline 14 & 0.89 & 2.544 & 68.984 & & & & & & \\
\hline 15 & 0.818 & 2.337 & 71.321 & & & & & & \\
\hline 16 & 0.775 & 2.214 & 73.535 & & & & & & \\
\hline 17 & 0.752 & 2.15 & 75.685 & & & & & & \\
\hline 18 & 0.693 & 1.979 & 77.665 & & & & & & \\
\hline 19 & 0.686 & 1.959 & 79.624 & & & & & & \\
\hline 20 & 0.651 & 1.861 & 81.484 & & & & & & \\
\hline 21 & 0.617 & 1.763 & 83.247 & & & & & & \\
\hline 22 & 0.589 & 1.684 & 84.931 & & & & & & \\
\hline 23 & 0.567 & 1.619 & 86.551 & & & & & & \\
\hline 24 & 0.548 & 1.566 & 88.117 & & & & & & \\
\hline 25 & 0.53 & 1.514 & 89.631 & & & & & & \\
\hline 26 & 0.493 & 1.408 & 91.039 & & & & & & \\
\hline 27 & 0.463 & 1.324 & 92.363 & & & & & & \\
\hline 28 & 0.424 & 1.212 & 93.575 & & & & & & \\
\hline 29 & 0.414 & 1.184 & 94.759 & & & & & & \\
\hline 30 & 0.365 & 1.042 & 95.8 & & & & & & \\
\hline 31 & 0.357 & 1.021 & 96.821 & & & & & & \\
\hline 32 & 0.327 & 0.934 & 97.755 & & & & & & \\
\hline 33 & 0.302 & 0.864 & 98.619 & & & & & & \\
\hline 34 & 0.267 & 0.763 & 99.382 & & & & & & \\
\hline 35 & 0.216 & 0.618 & 100 & & & & & & \\
\hline
\end{tabular}


Table 3

The summary of principal component analysis before rotation

\begin{tabular}{|c|c|c|c|c|c|c|c|c|c|c|c|c|c|}
\hline & \multirow{2}{*}{ Factor } & \multicolumn{12}{|c|}{ Component Matrix } \\
\hline & & 1 & 2 & 3 & 4 & 5 & 6 & 7 & 8 & 9 & 10 & 11 & 12 \\
\hline q3 & Financial Feasibility & 0.547 & & & & & -0.334 & & & & & & \\
\hline q19 & $\begin{array}{l}\text { Participation in venture } \\
\text { capital }\end{array}$ & 0.547 & & & & & & & & & & & \\
\hline q29 & $\begin{array}{l}\text { The pattern of business } \\
\text { process modeling }\end{array}$ & 0.541 & & & & & & & & & & & -0.462 \\
\hline q17 & Detection of new ideas & 0.538 & & & & & & & & & & & \\
\hline q1 & $\begin{array}{l}\text { Other researchers have } \\
\text { documented experience }\end{array}$ & 0.536 & & & & & & & & & & & \\
\hline q21 & $\begin{array}{l}\text { Protection of personal } \\
\text { and spiritual Market }\end{array}$ & 0.532 & & & & & & & & & & & \\
\hline q12 & Rates in the & 0.523 & & & & & & & & & & & \\
\hline q2 & $\begin{array}{l}\text { The success rate in the } \\
\text { experimental stage }\end{array}$ & 0.508 & & & & & & 0.373 & & & & & \\
\hline q23 & Innovation & 0.498 & & & & & & & & & & & \\
\hline $\mathrm{q} 4$ & $\begin{array}{l}\text { Technical and } \\
\text { administrative aspects of } \\
\text { the idea }\end{array}$ & 0.495 & & & & & & & & -0.433 & & & \\
\hline q11 & Identify the target market & 0.481 & & -0.394 & & & & & & & & & \\
\hline q9 & Insurance Research & 0.474 & & & & & & & & & -0.335 & & 0.34 \\
\hline q30 & Sift Ideas & 0.468 & & & & & & & & & & & \\
\hline q10 & Technical feasibility & 0.462 & & & & & & & & & & & \\
\hline q18 & Subject knowledge & 0.447 & & & & & & & -0.395 & & & & \\
\hline q15 & Attractive for investment & 0.443 & & & & & & & & & & 0.331 & \\
\hline q8 & $\begin{array}{l}\text { Analyze and evaluate the } \\
\text { needs of the market }\end{array}$ & 0.442 & & & & & & & & 0.435 & & & \\
\hline q27 & $\begin{array}{l}\text { Market-oriented research } \\
\text { ideas }\end{array}$ & 0.442 & & -0.418 & & & & & & & & & \\
\hline q16 & $\begin{array}{l}\text { Strategic needs of the } \\
\text { country }\end{array}$ & 0.426 & & & & 0.409 & 0.364 & & & & & & \\
\hline q14 & $\begin{array}{l}\text { Given the longevity of } \\
\text { ideas }\end{array}$ & 0.425 & & & 0.337 & & -0.396 & & & & & & \\
\hline q6 & $\begin{array}{l}\text { Competitiveness of } \\
\text { business }\end{array}$ & 0.404 & & & & -0.375 & & & & & & & \\
\hline q31 & $\begin{array}{l}\text { The possibility of having } \\
\text { an idea }\end{array}$ & 0.399 & & & & 0.33 & & & & & & 0.332 & 0.335 \\
\hline q34 & Learning organizations & & 0.787 & & & & & & & & & & \\
\hline q33 & $\mathrm{CE}$ & & 0.769 & & & & & & & & & & \\
\hline q36 & $\begin{array}{l}\text { Interaction with industry } \\
\text { and research teams }\end{array}$ & & 0.766 & & & & & & & & & & \\
\hline q35 & Participatory & & 0.763 & & & & & & & & & & \\
\hline q32 & $\begin{array}{l}\text { Responsibility in solving } \\
\text { community problems }\end{array}$ & & 0.656 & & & & & & & & & & \\
\hline q37 & $\begin{array}{l}\text { Support the organization } \\
\text { of ideas }\end{array}$ & & 0.563 & & & & & & & & & & \\
\hline q22 & $\begin{array}{l}\text { Acceptance of } \\
\text { commercial risk }\end{array}$ & 0.466 & & 0.493 & & & & & & & & & \\
\hline q7 & Government incentives & 0.46 & & 0.471 & & & & & & & & & \\
\hline q5 & Industry & 0.368 & & 0.439 & -0.35 & & & & & & & & \\
\hline q20 & Knowledge sharing & 0.461 & & & 0.522 & & & & & & & & \\
\hline q24 & $\begin{array}{l}\text { Administrative } \\
\text { bureaucracy problems }\end{array}$ & 0.434 & & & -0.343 & 0.458 & & & & & & & \\
\hline q26 & $\begin{array}{l}\text { Identify effective } \\
\text { marketing tool }\end{array}$ & 0.395 & & -0.352 & & & & & 0.458 & & & & \\
\hline q25 & $\begin{array}{l}\text { Market demand for } \\
\text { certain }\end{array}$ & 0.461 & & & & & & & & & 0.591 & & \\
\hline
\end{tabular}


Table 4

The summary of principal component analysis after rotation

\begin{tabular}{|c|c|c|c|c|c|c|c|c|c|c|c|c|c|}
\hline & \multirow{2}{*}{ Factor } & \multicolumn{12}{|c|}{ Rotated Component Matrix ${ }^{a}$} \\
\hline & & 1 & 2 & 3 & 4 & 5 & 6 & 7 & 8 & 9 & 10 & 11 & 12 \\
\hline q33 & $\mathrm{CE}$ & 0.807 & & & & & & & & & & & \\
\hline q34 & Learning organizations & 0.803 & & & & & & & & & & & \\
\hline q35 & Participatory Management & 0.777 & & & & & & & & & & & \\
\hline q36 & $\begin{array}{l}\text { Interaction with industry } \\
\text { and research teams }\end{array}$ & 0.754 & & & & & & & & & & & \\
\hline q32 & $\begin{array}{l}\text { Responsibility in solving } \\
\text { community problems }\end{array}$ & 0.631 & & & & & & & & & & & \\
\hline q37 & $\begin{array}{l}\text { Support the organization of } \\
\text { ideas }\end{array}$ & 0.504 & & & & & & & & & & & \\
\hline q20 & Knowledge sharing & & 0.729 & & & & & & & & & & \\
\hline q30 & Sift Ideas & & 0.615 & & & & & 0.355 & & & & & \\
\hline q17 & Detection of new ideas & & 0.592 & & & & & & & & & & \\
\hline q14 & Given the longevity of ideas & & 0.55 & & & & & & & & & & \\
\hline q12 & $\begin{array}{l}\text { Rates in the } \\
\text { commercialization of ideas }\end{array}$ & & & 0.701 & & & & & & & & & \\
\hline q2 & $\begin{array}{l}\text { The success rate in the } \\
\text { experimental stage }\end{array}$ & & & 0.64 & & & & & & & & & \\
\hline q3 & Financial Feasibility & & & 0.473 & & & & & & & & & \\
\hline q10 & Technical feasibility & & & 0.435 & & & & & & & & & \\
\hline q8 & $\begin{array}{l}\text { Analyze and evaluate the } \\
\text { needs of the market }\end{array}$ & & & & 0.696 & & & & & & & & \\
\hline q27 & $\begin{array}{l}\text { Market-oriented research } \\
\text { ideas }\end{array}$ & & & & 0.573 & & & & & & & & \\
\hline q25 & Market demand for certain & & & & 0.57 & 0.331 & & & & & & & \\
\hline q11 & Identify the target market & & & & 0.477 & & & & & & & 0.4 & \\
\hline q19 & $\begin{array}{l}\text { Participation in venture } \\
\text { capital }\end{array}$ & & & & & & & & & & & & \\
\hline q6 & $\begin{array}{l}\text { Competitiveness of } \\
\text { business }\end{array}$ & & & & & 0.701 & & & & & & & \\
\hline q4 & $\begin{array}{l}\text { Technical and } \\
\text { administrative aspects of }\end{array}$ & & & & & 0.699 & & & & & & & \\
\hline q9 & Insurance Research & & & & & & 0.632 & & 0.403 & & & & \\
\hline q7 & Government incentives & & 0.379 & & & & 0.576 & & & & & & \\
\hline q21 & $\begin{array}{l}\text { Protection of personal and } \\
\text { spiritual Market }\end{array}$ & & & & & 0.448 & 0.571 & & & & & & \\
\hline q5 & Industry & & & & & & & 0.721 & & & & & \\
\hline q16 & $\begin{array}{l}\text { Strategic needs of the } \\
\text { countrv }\end{array}$ & & & & & & & 0.703 & & & & & \\
\hline q24 & $\begin{array}{l}\text { Administrative bureaucracy } \\
\text { problems }\end{array}$ & & & & & & & & 0.678 & 0.333 & & & \\
\hline q23 & Innovation & & & & & & & & 0.583 & & & & \\
\hline q31 & $\begin{array}{l}\text { The possibility of having an } \\
\text { idea }\end{array}$ & & & & & & & & & 0.718 & & & \\
\hline q15 & Attractive for investment & & & & & & & & & 0.612 & & & 0.382 \\
\hline q18 & Subiect knowledge & & & & & & & & & & 0.722 & & \\
\hline q1 & $\begin{array}{l}\text { Other researchers have } \\
\text { documented experience }\end{array}$ & & & 0.342 & & & & & & & 0.522 & & \\
\hline q26 & $\begin{array}{l}\text { Identify effective marketing } \\
\text { tool }\end{array}$ & & & & & & & & & & & 0.733 & \\
\hline q22 & $\begin{array}{l}\text { Acceptance of commercial } \\
\text { risk }\end{array}$ & & & & & & & 0.359 & & & & -0.513 & \\
\hline q29 & $\begin{array}{l}\text { The pattern of business } \\
\text { process modeling }\end{array}$ & & & & & & & & & & & & 0.751 \\
\hline
\end{tabular}

According to the results of Table 4, we may extract the necessary factors and Table 5 summarizes the results of our survey. 
Table 5

The summary of the results of factors influencing SMEs promotion

\begin{tabular}{cclc}
\hline Variable & Question & Components & Factor loading \\
\hline \multirow{3}{*}{ Organizational } & q33 & CE & 0.807 \\
learning strategy & q34 & Learning organizations & 0.803 \\
& q35 & Participatory Management & 0.777 \\
& q36 & Interaction with industry and research teams & 0.754 \\
& q32 & Responsibility in solving community problems & 0.631 \\
\hline \multirow{4}{*}{ Management idea } & q37 & Support the organization of ideas & 0.504 \\
& q20 & Knowledge sharing & 0.729 \\
& q30 & Sift Ideas & 0.615 \\
\hline \multirow{3}{*}{ The feasibility of the } & q17 & Detection of new ideas & 0.592 \\
idea & q14 & Given the longevity of ideas & 0.55 \\
\hline \multirow{4}{*}{ Market research } & q12 & Rates in the commercialization of ideas & 0.701 \\
& q2 & The success rate in the experimental stage & 0.64 \\
\hline \multirow{3}{*}{ Advocacy strategies } & q3 & Financial Feasibility & 0.473 \\
& q10 & Technical feasibility & 0.435 \\
\hline & q27 & Analyze and evaluate the needs of the market & 0.696 \\
\hline
\end{tabular}

According to the results of Table 5, there are five factors associated with the proposed study including, organizational learning strategy, management of idea, the feasibility of the idea, market research and advocacy strategies.

\section{Discussion and Conclusion}

Export has been the primary source of economic development and it is always important to find important factors influencing on creating new ideas to boost export activities. This paper has presented an empirical investigation to find important factors influencing on development of commercializing new ideas for business development in SMEs in Iran. The study has used structural equation modelling to investigate the effects of various factors and has detected five factors. The first item, organizational learning strategy, consists of five sub-components including CE, learning organizations, participatory management, Interaction with industry and research teams, Responsibility in solving community problems and Support the organization of ideas. The second factor, management idea, consists of four factors where knowledge sharing is the most important one followed by shift ideas and detection of new ideas. The feasibility of the idea is the other important factor where rates of commercializing the idea is the most important factor followed by the success rate in the experimental stage as well as financial and technical feasibility. Market research is another important factor in our survey, which consists of four factors where market assessment is the most important one followed by market oriented research ideas. Finally, advocacy strategies are the last item of the survey where having insurance for research is the most important factor.

\section{Acknowledgement}

The authors would like to thank the anonymous referees for constructive comments on earlier version of this work.

\section{References}

Audretsch, D. B., \& Thurik, A. R. (2004). A model of the entrepreneurial economy. International Journal of Entrepreneurship Education, 2(2), 143-166.

Brinkley, I. (2006). Defining the knowledge economy. London: The work foundation, 19. 
Creswell, J. W. (2002). Educational research: Planning, conducting, and evaluating quantitative. Prentice Hall.

Danaei, H \& Normohammadi, M. (2013). An empirical study on relationship between intellectual capital and organizational entrepreneurship: A case study of Islamic Azad university of Semnan. Management Science Letters, 3(5), 1339-1344.

Derakhshandeh, A. (2013). A study on organizational entrepreneurship on economic growth. Management Science Letters, 3(1), 297-302.

Duane Ireland, R., \& Webb, J. W. (2007). Strategic entrepreneurship: Creating competitive advantage through streams of innovation. Business Horizons, 50(1), 49-59.

Gartner, W. B. (2007). Is There an Elephant in Entrepreneurship? Blind Assumptions in Theory Development. In Entrepreneurship (pp. 229-242). Springer Berlin Heidelberg.

Hayton, J. C., George, G., \& Zahra, S. A. (2002). National culture and entrepreneurship: A review of behavioral research. Entrepreneurship Theory and Practice, 26(4), 33-52.

Karimi, P., Kloshani, M \& Bakhshizadeh, A. (2012). A comparative study on emotional intelligence and cognitive between successful and unsuccessful entrepreneurs. Management Science Letters, 2(6), 2071-2076.

Kreiser, P. M., Marino, L. D., \& Weaver, K. M. (2002). Assessing the psychometric properties of the entrepreneurial orientation scale: A multi-country analysis. Entrepreneurship Theory and Practice, 26(4), 71-94.

Nasrabadi, Z., Nikbakht, A \& Rad, A. (2012). A social work study on different entrepreneurship opportunities. Management Science Letters, 2(6), 2231-2236.

Nicholson, N., \& de Waal-Andrews, W. (2005). Playing to win: Biological imperatives, self-regulation, and trade-offs in the game of career success. Journal of Organizational Behavior, 26(2), 137-154.

Sarasvathy, S. D., \& Venkataraman, S. (2011). Entrepreneurship as method: open questions for an entrepreneurial future. Entrepreneurship Theory and Practice, 35(1), 113-135.

Soysekerci, S., \& Erturgut, R. (2010). Improvement of non-governmental organization entrepreneurship in vocational schools: Turkey case. Procedia-Social and Behavioral Sciences, 2(2), 1849-1854.

Thurik, R., \& Wennekers, S. (2004). Entrepreneurship, small business and economic growth. Journal of Small Business and Enterprise Development, 11(1), 140-149.

Turró, A., Urbano, D., \& Peris-Ortiz, M. (2013). Culture and innovation: the moderating effect of cultural values on corporate entrepreneurship. Technological Forecasting and Social Change, 88, 360-369.

Verheul, I., Wennekers, S., Audretsch, D., \& Thurik, R. (2002). An eclectic theory of entrepreneurship: policies, institutions and culture. InEntrepreneurship: Determinants and policy in a European-US comparison (pp. 11-81). Springer US. 